\title{
Revenue and expenditure of timber depots and constraints faced by forest officials and intermediaries in Uttara Kannada district
}

\author{
Srishti Thakur and C. Murthy
}

Received : 07.07.2018; Revised : 06.09.2018; Accepted : 17.09.2018

\begin{abstract}
The present study was undertaken to investigate the policies which will help in increasing the revenue, constraints faced by the forest officials and intermediaries in the study area. For this purpose three main depots having highest revenue realised after sales from canara circle were selected. Secondary data pertaining to the study were collected from the records maintained by the forest timber depots for the period of 12 years (2005-06 to 2016-17) and primary data were collected to know the constraints faced by the forest officials and intermediaries. Compound growth rate analysis and Garrett's ranking techniques were employed to analyse the data. The results revealed that positive and significant growth rate for revenue in Dandeli forest timber depot while growth rate for revenue in Kirwatti and Chipgi forest timber depots were negative, whereas the growth rate in expenditure for all the three depots were significant and positive. The further studies showed that wastage of wood was the main constraint for forest officials and lack of knowledge about e-auctioning was the major constraints faced by the intermediaries in buying the timber.
\end{abstract}

KEY WORDS : Revenue, Expenditure, Compound growth rate, Constraint for forest officials, Intermediaries

How to cite this paper : Thakur, Srishti and Murthy, C. (2018). Revenue and expenditure of timber depots and constraints faced by forest officials and intermediaries in Uttara Kannada district. Internat. J. Com. \& Bus. Manage, 11(2) : 121-126, DOI: 10.15740/HAS/IJCBM/ 11.2/121-126. Copyright@ 2018: Hind Agri-Horticultural Society. 